DOI https://doi.org/10.30525/978-9934-588-79-2-2.39

\title{
ПЕРСПЕКТИВИ СТВОРЕННЯ РУХОМОГО ЗАСОБУ З НАКОПИЧЕННЯМ ЕНЕРГІЇ ОБЕРТАННЯ В ЗОНІ ПЛЯМИ КОНТАКТУ КОЛІСНОГО РУШІЯ І ОПОРНОЇ ПОВЕРХНІ
}

\author{
Петров Л. М. \\ кандидат технічних наук, доцент, \\ кафедра автомобільної техніки \\ Військова академія (м. Одеса) \\ Кішянус I. В. \\ старший викладач, \\ кафедра автомобільної техніки \\ Військова академія (м. Одеса) \\ Петрик Ю. М. \\ старший викладач, \\ кафедра автомобільної техніки \\ Військова академія (м. Одеса) \\ м. Одеса, Україна
}

Світові автомобілебудівники спрямовуються своїм зусилля на удосконалення конструкції автомобілів для підвищення ефективності їх експлуатації.

Одним із перспективних способів підвищення паливної економічності будівельно - дорожніх машин як циклічного, так і непереривної дії являється побудова гібридних машин і силових установок, (рис. 1) $[2$, c. 2].

Електричні гібриди широко використовуються в автомобільному транспорті і розробляються практично всіма видатними фірмами виробниками: BMW, Mersedes, Volvo. На будівельно-дорожніх машинах енергозберігаючі системи втілюються такими фірмами як Catapiller, Volvo i інш. В автомобілі Volvo FE Hybrid застосовується гібридна силова енергетична установка в вигляді дизельного двигуна і зворотної електромашини, які під дією системи керування можуть працювати як разом, так і окремо [1, с. 11-14]. При цьому перемикання між режимами роботи здійснюється автоматично відповідними елементами системи управління. Силова енергетична установка (рис. 1) транспортного засобу нового покоління Volvo FE Hybrid включає в себе: дизельний двигун $D$; зчеплення; коробку перемінних передач (КПП) 
I-Shift (I); систему MDS в вигляді зворотного електротехнічного комплексу, яке містить в своєї основі функціональні можливості стартера (електродвигуна $G$ постійного струму) і генератора $E$; блок PMU управління енергетичною установкою, яка координує роботу іiї основних частин; блок $B$ акумуляторів.

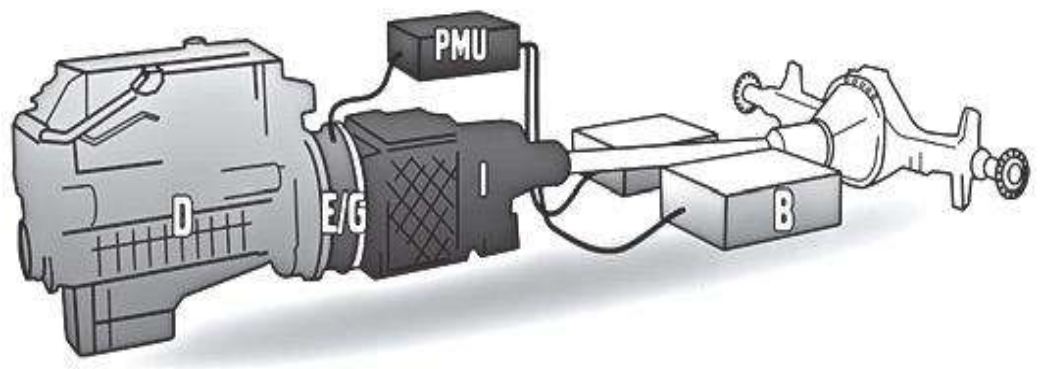

Рис. 1. Схема гібридного привода Volvo

Економічність і надійність експлуатації автомобіля Volvo $\mathrm{FE}$ Hybrid, а також його безпека для навколишньої середи свідчить об ефективності гібридної технології, яка використовується в його конструкції.

Спосіб переміщення тягово - транспортної системи за допомогою поштовху колісного рушія в зоні його стиснення та осередку обертання може бути виконаний за конкретним прикладом (рис. 2) [3, с. 1]. Запропонований спосіб включає тягово - транспортну систему 1 , до колісного рушія 2 за допомогою гребінки 3 , важеля 4 та динамічної ваги 5 і підтримуючого ролика, які за допомогою важеля 4 та ланки 7 шарнірно закріплені на осі 8 , на якій закріплений колісний рушій. До ланки 7 жорстко приєднаний важіль 9 з загнутим кінцем 10. До зігнутого кінця 10 горизонтальним шарніром 11 під'єднано важіль поштовху 12. Важіль поштовху за допомогою вертикального шарніру 13 опирається на опорну поверхню керуючим колесом 14. На вертикальній осі співвісно закріплено стабілізатор стійкості 15. Загнутий кінець 10 важеля 9 кінематично за допомогою пружини розтягу 16 зв'язано 3 важелем поштовху 12.

Спосіб переміщення тягово - транспортної системи за допомогою поштовху колісного рушія в зоні його стиснення та осередку обертання здійснюють таким чином. 
При здійсненні процесу переміщення тягово - транспортної системи 1 колісний рушій 2 починає обертати в напрямку руху проти годинникової стрілки і за допомогою гребінки 3 динамічна вага 5 відхиляється в тому ж напрямку, важіль 4 вигинається, накопичуючи при цьому потенціальну енергію. Одночасно 3 цим жорстко поєднаний важіль 9 з загнутим кінцем 10 відхиляється вгору, пружина 16 стискається, а керуюче колесо 14 наближається до колісного рушія 2 за допомогою важеля поштовху 12, який повертається в горизонтальному шарнірі 11. При виконанні таких операційних дій ланка 7 та підтримуючий ролик 6 стабілізують заданий рух важеля 9 відносно динамічної ваги 5, а вертикальний шарнір 13 із стабілізатором стійкості 15 забезпечують копіювання руху відносно повздовжньої осі тягово транспортної системи 1. У процесі руху тягового - транспортної системи 1 динамічна вага 5, яка відхилена на величину висоти гребінки 3 під дією вивільнення енергії стиснутої пружини розтягу 16 отримує силу поштовху. Сила поштовху передається за допомогою загнутого кінця 10 жорстко приєднаного важеля 9 та ланки 7. Одночасно, підтримуючий ролик 6 перекочується по диску, забезпечує ланку 7 зайняти вертикальне положення. В подальшому процес повторюється.

Запропонований спосіб тягово - транспортної системи за допомогою поштовху колісного рушія в зоні його стиснення та осередку обертання нами був реалізований у макетному зразку (рис. 3) [3, с. 4].

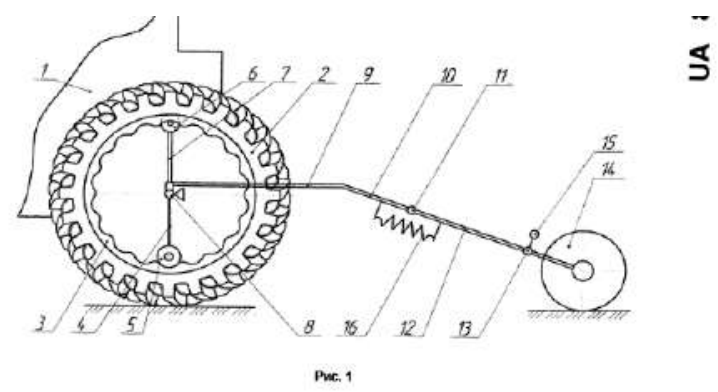

\section{Рис. 2. Спосіб переміщення тягово-транспортної системи за допомогою поштовху колісного рушія в зоні його стиснення та осередку обертання}




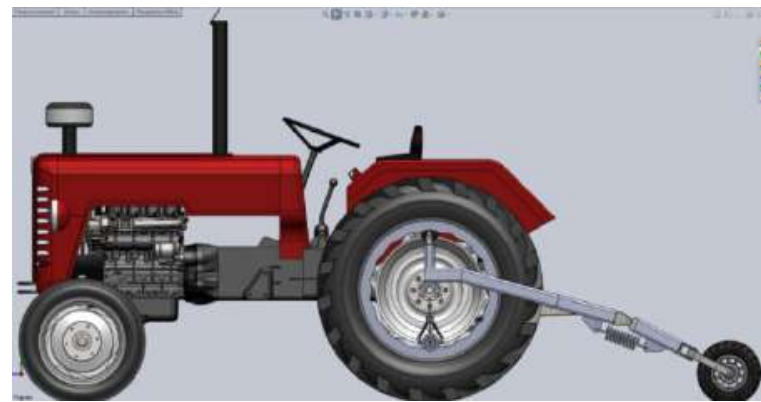

Рис. 3. Макетний зразок способу переміщення тягово-транспортної системи за допомогою поштовху колісного рушія в зоні його стиснення та осередку обертання

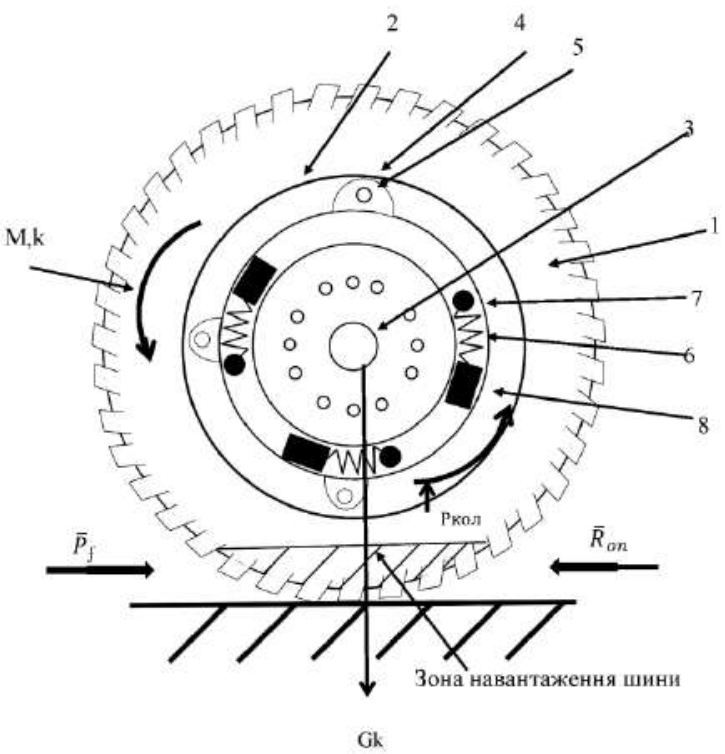

Рис. 4. Колісний рушій 3 подвійним динамічним навантаженням

1 - Шина, 2 - диск, 3 - ступиця, 4 - ухо, 5 - футорка, 6 - пружина, 7 - жорстке кріплення пружини, 8 - динамічна вага 
Коефіціент тяги колісного рушія з подвійним динамічним навантаженням будемо оцінюєти згідно запропонованої формули формули:

$$
\varphi=\frac{\text { Rоп }+ \text { Ркол }-\mathrm{P} f}{\mathrm{G \kappa}}
$$

Де, Rоп - реакція опорної поверхні;

Ркол - колове навантаження колісного рушія;

$\mathrm{Pf}$ - опір коченню колісному рушію

Gк - вертикальне навантаження на колісний рушій.

Висновки. В тезах розглянуто розвиток конструкцій перспективи розробки автомобільних технологій спрямованих на зменшення витрат енергії у зв'язку з виконанням ними роботи. Приведені особливості конструктивних схем автомобільних технологій. Проаналізовані переваги та недоліки таких технологій. Запропонована схема колісного рушія, яка на даному етапі розвитку конструкцій автомобілів дозволить вирішити існуючу проблему за рахунок подвійної динаміки колісного рушія. Тези призначені для спеціалістів в галузі технології переміщення автомобілів.

\section{Література:}

1. Балезин H.M. Гібридний автомобіль Volvo FE HYBRID / Н.М. Балезин // Будівельні і дорожні машини. - 2014. - № 2. - С. 11-14.

2. Хмара Л.А., Холодов А.П. Перспективи побудови енергозберігаючих будівельно-дорожніх машин і удосконалення гідроакумулючих систем. - Вестник ХНАДУ, вип. 65-66, 2014. С. 28-34.

3. Петров Л.М., Борисенко Т.М. «Спосіб переміщення тяговотранспортної системи за допомогою поштовху колісного рушія в зоні його стиснення та осередку обертання. 10.12.2013, Бюл. № 23. 